\title{
The Place and Importance of Malgudi in the novels of .K. Narayan
}

\author{
Dr Sudarsan Sahoo \\ Department of English Parala Maharaja Engineering College Sitalapalli, Berhmapur ,Odisha India
}

\begin{abstract}
R.k.Narayan is a prolific Indian writer writing in English. His Fictions are immensely popular in India and abroad. Malgudi is the central focus of his imagination. This prominent place of the writer is the eternal source of the pleasures and sorrows of the characters of the novel. The writer the multitude sides of this imaginative location in almost all his novels. The chararacters presented in the fictions feel quite secured in the environment of Malgudi.Malgudi is really a dream for the readers.
\end{abstract}

Keywords: Lalgudi, Mempi Hills, Malgudians, Nellap's Groove, Sarayu River,

Malgudi is the fictional setting of R.K. Narayan's novels and stories. This place has comparable standard to the other writers of English Literature. It is compared to 'boarder countries' of Sir Walter Scott , 'Lake District' of William Wordsworth ,'The Wessex' of Thomas Hardy, or 'five Towns' of Arnold Bennet.Malgudi is an imaginary South Indian town round which Narayan has woven the complex pattern of the lives of his characters. The readers are taken to this imaginary land to laugh ,sympathise , and share the vicissitudes of its inhabitants.

This imaginary setting came to Narayan's mind instantly:

I remember waking up with the name Malgudi on Vijayadashami ,the day on which the goddess of learning is celebrated. Malgudi was an shaking discovery for me because I had no mind for facts and things like that, which would be necessary in writing about Malgudi or any real place. I first pictured not my town but just the railway station, which was a small platform with a banayan tree, a station master , and two trains a day ,one coming and one going. On Vijayadashami, I sat down and wrote the first sentence about my town: "the train had just arrived at Malgudi station.'

Hatri,Chote Lal,R.K. Narayan :Reflections and R-evaluation(Sarup and Sons, New Delhi,2006)(62)

Malgudi does not exist on any map of India.It is Lalgudi in Trichinapoly District, fringing the river Cavery which can be taken for the original of Malgudi.It is neither a village nor city ,but a town of modest size. It lives in the imagination more distinctly than any other region described by any Indian writer.Narayan's Malgudi is a reality charged with all that is intimate and poignant in human life.It is associated with the rise and fall of heroes and heroines.Narayan's first novel 'Swami and Friends' introduces us to this town called Malgudi on the boarder of the states of Mysore and Madras. Malgudi has a municipality , a town Hall ,a club and two schools - The Albert Mission School,and the Board High School.

The principal landmarks of Malgudi -Malgudi station, the central co-operative Land Mortgage Bank, The Bombay Anand Bhawan ,Kabir Street ,Lawley Extension ,the Regal Hair-cutting Saloon, the statue of Sir Frederic Lawley, the Sarayu River,Nallapa's Groves, Mempi Hills ,Hotels, cinemas make a social framework of the novel. Malgudi passes through many changes with the passage of time. The characters in various novels pass through various stages of development. In 'Swami and Friends' ,Malgudi is neither a village nor a city ,but a town of modest size,but in successive novel it grows in time and place. The writer expresses the picture of this imaginary island in different novels differently:

It has grown from the small sized agricultural town to a semi industrialised city. The Malgudi of Swami and Friends is not the same as as the Malgudi of The Vendor of Sweets. Even in the same novel in The Guide, we see it passing through various phases of development. Speaking from the topographical point of view,the Albert Mission college ,headed by Principal Brown ,the Central Co-operative land mortage bank with its imposing structure, the newly -built bungalows in the lawly Extension, Englandia Banking Corporation, The Sunrise Pictures , all speak emphatically of the story of the growth of the town.

Walsh, William, R.K.Narayan (Allied publishers,New Delhi ,2005) (34)

In the novels of R.K. Narayan, the characters are malgudians deeply rooted in the age -old local traditions and they entirely belong to Malgudi in every sense and aspect.Malgudi is of all absorbing interest to the readers of R.K.Narayan.It is not a mere geographical expression, it has a distinct personality of its own.N.Mukherjee finds Malgudi as the real hero of Narayan's novels and stories. 
It is Narayan's triumph as an artist that makes us have complete faith faith in the reality of Malgudi. It is so strongly implanted in our imagination that we wonder whom we are going to meet in this town.......The streets and the lanes appear to as familiar as one's home town.

Mukherjee,N.K,Indian Writing in English(Sterling Publishers Pvt.Ltd.New Delhi ,2002)(78)

R. K.Narayan describes the the sights, sounds and smells of this imaginary place with much accuracy and vividness. Even the minute things seem typical of Malgudi.N.Mukherjee explains the natural sights, sounds and flavour of this place:

The smells ,sights, sounds and the flavour that are all parts of the experience of being in Malgudi are conveyed with an ever-extraordinary vividness.

Mukherjee,N.K,Indian Writing In English(Sterling Publishers Pvt.Ltd.New Delhi.2002)(70)

In the novels of R.K.Narayan ,Malgudi is a symbol of contemporary India. This place is a small town with its high school ,cricket ground ,temple and market place. It changes with the advancement of time as it acquires a film sudio, a road bridge on the river , a college and other amenities of modern civilization. The protagonists of different fictions like Swami in Bachelor of Arts ,Krishnan in English Teacher ,Margayya in Financial Expert ,Raju in Guide are the living personalities Malgudi.

The speciality of the locale of the Malgudi setting is its reluctance for gradual changes. Life here moves at slow pace. It is completely undisturbed by the outside world. There is no outside interference in the peace and tranquillity of this place. The people of the Malgudi have strong faith on the traditions and customs of the place. The setting of the Malgudi is quite distinctive and the most part of the place is descriptive. The places of Malgudi are not overshadowed by the people who inhabit it and they have nothing of special quality of their own. The portrayal of life is the main objective Narayan and it is adequate for the setting of Malgudi. There are characters who give meaning to the places of Malgudi and make them real and life -like. There is a sence of familiarity of the place and streets of Malgudi.It is homebred.It helps the readers to be intimate.It creates a deeper and better understanding of its people and places establishing a close intimacy.There is no separate identity of Malgudi without its financial expert ,Margayya, its printer,Sampath,its editor, Srinivas,and its holy man, Raju.

Malgudi is the comic projection of Narayan.It is an imaginary town in which nationalists and nationalism are treated with the same comic irony. This comic irony is deployed against cheats, bohemians,bossy wives and indulgent grandparents. This clearly indicates the maturity and artistic visions of the novelist.The Malgudi of India is treated in same line as R.K.Narayan treats. It is full of knaves ,prostitutes ,lehers,adulters, money-grabbers ,drunkards,sanyasi,and would be gangsters. The place is full of chaos. Husbands are betrayed by their wives. Men are captivated by the false beauty of actresses and the female sex.There are children revolting against parents and and the old ways of life. There is a sence of misery and happiness in reading the novels of R.K.Narayan.Like the tragedies of William Shakespeare, there is a touch of sadness and disillusionment. The creations of R.K.Narayan compel the readers to face the tragic as well as comic views of life without any hesitations.

Malgudi is a place where people are not heroic. There is no control over the events but it seems as if they control everything .They are utterly helpless creatures torn by desire .There is a divine force controlling the characters of the fictions .Chandra of The Bachelor of Arts at last runs away from home .Mr.Sampath is impelled by fortune and at last leaves Malgudi forever. The English Teacher finds happiness in the world of spirits after the death of his wife. The Guide dies as a ruined man not because he wants to conspire death. The circumstance is not supportive and he decides to be as willing martyr. The people of Malgudi are mere puppets in the hand of fate. The ultimate fate seems to be the decider for the happiness or unhappiness of the dwellers of Malgudi. The different characters of the fiction are representative figures Malgudi. The characters prefer to become sanyasi if they are defeated in life. If they realise that the circumstance is not favourable, they surrender the ultimate force of the universe.Narayan has given solution for the evils of life :"If you are defeated ,run away."

Narayan underlines the timeless quality of Malgudi in spite of disturbances and changes inside and outside. His craftsmanship lies not only in the classical conventional life of Malgudian India, but in the loving attention he devotes to building up a real picture of Malgudi and its inhabitants. Malgudi has its greatest characters with its Mempi hills, tiger -haunted jungles ,Natraj printing shop,Jagan's sweet emporium,Jonsonian human characters like Mr.Sampath.Narayan finds plenty of comedy in the normal life of Malgudi without a Vasu to complicate it. There is a mempi malgudi Bus depot. There is 'Mahaut' to persuade the elephant to walk to Malgudi. There is a poet at war with 'all disyllables.......polysyllables' in his great Krishna poem. There is peculiar comic personality of 'The Man Eater'. Still Narayan's attitude towards Malgudi remains lovingly ambiguous. He loves to depict the traditional life of Malgudi with all its backwardness and peculiarities.But he treats it with gentle teasing and melancholy understanding. The treatment of the psychology of the characters is subtle and beautiful. 
The procession of extraordinary characters that marches through Malgudi consists of animal stuffer ,crooked politicians, the adjournment lawer,film producers, village idiots and the temple prostitutes. The reality of Malgudi is also displayed in his short stories. Malgudi is lively with with its collection of printing shops,schools ,temples, hotels and mempi hills.It has usual beggars ,spongers ,tricksters ,bohemians and orthodox community. Malgudi is less tolerant of the modenisers ,Americanizers and Anglicizers,Government planners , men of violence, fanaticism and needless novelty. So Malgudi takes characters of its own. The themes ,characters and dialogue echo the sound of Malgudi.

Narayan is not a scientist in fiction. He is a realist and gives details of life he depicts. He does not comprehend the whole of the reality but the realism creeps up as the selective tendency in the descriptive part of his fictional world. The reality of Malgudi has got to be appreciated because of the detailed relevance to the subjects he has treated. He does not paint a serious picture of life .It is rather comic-tragic view of life. His approach to life is very comic. It is realistic, ironic ,pathetic and yet comic. Some of the incidents are dramatic ,introspective and moralizing. The common factor in most of his novels is that the main character grows from an average to an influential human being and then comes back to his normal status.

Narayan is at his best giving his fictional setting of Malgudi a reality of his own. His energy has been spent over the details of the characters and the manners of the people moving over the canvas of Malgudi. Their individual traits and habits have been depicted with certain relevant details.Narayan portrays -Marco of The Guide intensely interested in his own researches. He is also very particular about the vouchers.Raju's father takes keen interest in talks regarding litigation. The manners of Raju from tourist guide to the holy man change according to the exigencies of the situation ,but his manners remains almost the same throughout. In this way the reality of Malgudi is directly or indirectly the reality of the manners of characters ,their places ,their attitudes ,their taste and poise of their personalities. Narayan's reality of Malgudi is the presentation of different human attitudes individually differing in their environment in a most realistic manner. It is usually built round Indian beliefs and superstitions. The smells, sights, sounds and flavours form the part of the experience of Malgudi. They are conveyed to all of us with extraordinary vividness.

\section{References}

[1]. Khatri ,Chhote ,Lal ,R.K.Narayan Reflections and Re-evaluation(Sarup @ Sons,New Delhi ,2006)[1\}

[2]. Walsh,William,R.K.Narayan(Allied Publishers ,New Dehli ,2006)[2]

[3]. Mukherjee,N.k.Indian Writing in English(Sterling publishers pvt.Ltd ,New Delhi ,2002) [3][4]

[4]. K.R.S. Iyenger:Indian Writing in English(Sterling Publisher, 1990).

[5]. Naraya, R.K., The Dark Room ,(Indian Thought Publication,Mysore,1970).

[6]. R.K.Narayan,The Guide(Indian Thought Publication,Mysore.1958).

[7]. R.K.Narayan, The Waiting For Mahatma (Indian thought Publication,Mysore, 1970).

[8]. R.k.narayan,The Bachelor of Arts ( Indian thought publication ,Mysore, 1972).76.G.N.Agnihotri, Indian Life and Problems in the novels of Mulk Raj Anand ,Raja Rao and R.K.Narayan (Saru publishing House,New Delhi, 1984). 